\title{
Correlation and Late-Stage Deformation of Liv Group Volcanics in the Ross-Delamerian Orogen, Antarctica, from New U-Pb Ages
}

\author{
Timothy S. Paulsen, ${ }^{1, \star}$ Iohn Encarnación, ${ }^{2}$ Anne M. Grunow, ${ }^{3}$ Edmund Stump, ${ }^{4}$ \\ Mark Pecha, ${ }^{5}$ and Victor A. Valencia ${ }^{6}$
}

1. Department of Geology, University of Wisconsin, Oshkosh, 800 Algoma Boulevard, Oshkosh, Wisconsin 54901, USA; 2. Department of Earth and Atmospheric Sciences, St. Louis University, 3242 Lindell Boulevard, O'Neil Hall 205, St. Louis, Missouri 63108, USA; 3. Byrd Polar Research Center, Ohio State University, 108 Scott Hall, 1090 Carmack Road, Columbus, Ohio 43210, USA; 4. School of Earth and Space Exploration, Arizona State University, Tempe, Arizona 85287, USA; 5. Department of Geosciences, University of Arizona, Gould-Simpson Building, 1040 East Fourth Street, Tucson,

Arizona 85721, USA; 6. School of the Environment, Washington State University, Pullman, Washington 99164-2812, USA

\begin{abstract}
A B S T R A C T
We present new zircon U-Pb isotopic data for volcanic rocks from deformed metavolcanic-sedimentary successions of the widespread Ross Supergroup in the Queen Maud Mountains, Antarctica. Zircon U-Pb analyses of Liv Group volcanic rocks thought to be Neoproterozoic in age instead have early Paleozoic ages. Zircon U-Pb analyses of five samples assigned to the Fairweather Formation have yielded $524 \pm 9$ to $514 \pm 9 \mathrm{Ma}(2 \sigma)$ crystallization ages, whereas six samples assigned to the Taylor Formation have yielded $510 \pm 12$ to $490 \pm 6 \mathrm{Ma}(2 \sigma)$ crystallization ages. Although these ages imply that the Fairweather Formation is generally older than the Taylor Formation, the age uncertainties show a 17-My overlap that is consistent with previous suggestions for temporal correlation of these formations. On a regional scale, Liv Group volcanism overlapped with the emplacement of 535-490 Ma plutonic rocks associated with the early Paleozoic Queen Maud batholith as well as igneous rocks found elsewhere along the early Paleozoic PacificGondwana margin. Collectively, these igneous rocks provide plausible zircon sources for similar age detrital zircon populations found in outboard siliciclastic rocks belonging to the Leverett, Taylor, Fairweather, Greenlee, and Starshot Formations of the Queen Maud Mountains. The youngest crystallization age yielded by the deformed Taylor Formation ( 490 Ma) assumes regional significance because it represents the youngest volcanic rock yet identified within the Ross orogen in Antarctica and provides important new evidence for latest Cambrian or younger deformation, possibly associated with orogenic collapse during slab rollback at the terminal stages of the Ross orogeny.
\end{abstract}

Online enhancements: supplemental table.

\section{Introduction}

The late Neoproterozoic-early Paleozoic RossDelamerian orogenic belt forms part of a greater collage of igneous, sedimentary, and metamorphic rocks that collectively comprise a subduction-related accretionary belt along Gondwana's paleo-Pacific margin known as the Terra Australis orogen (fig. 1; Boger 2011). Rocks of the Ross-Delamerian orogenic belt are presently exposed unconformably beneath unmetamorphosed Devonian-Jurassic sedimentary rocks of

Manuscript received January 9, 2017; accepted January 13, 2018; electronically published March 13, 2018.

* Author for correspondence; email: paulsen@uwosh.edu.

the Beacon Supergroup (Barrett 1991) in the Transantarctic Mountains, a major rift flank mountain range located on the margin of the Mesozoic-Cenozoic West Antarctic Rift system (Fitzgerald et al. 1986). Igneous, sedimentary, and metamorphic rocks of the Ross orogen are of widespread interest because of their significance for understanding the tectonic history of Gondwana's paleo-Pacific margin (Stump 1992; Encarnación and Grunow 1996; Grunow et al. 1996b; Goodge 1997; Goodge et al. 1993, 2002, 2004a, 2004b; Cawood 2005; Boger 2011) and the possibility that they may offer insight into the Cambrian explosion of life, since the sediment flux caused by erosion of

[The Journal of Geology, 2018, volume 126, p. 307-323] (c) 2018 by The University of Chicago. All rights reserved. 0022-1376/2018/12603-0003\$15.00. DOI: 10.1086/697036 


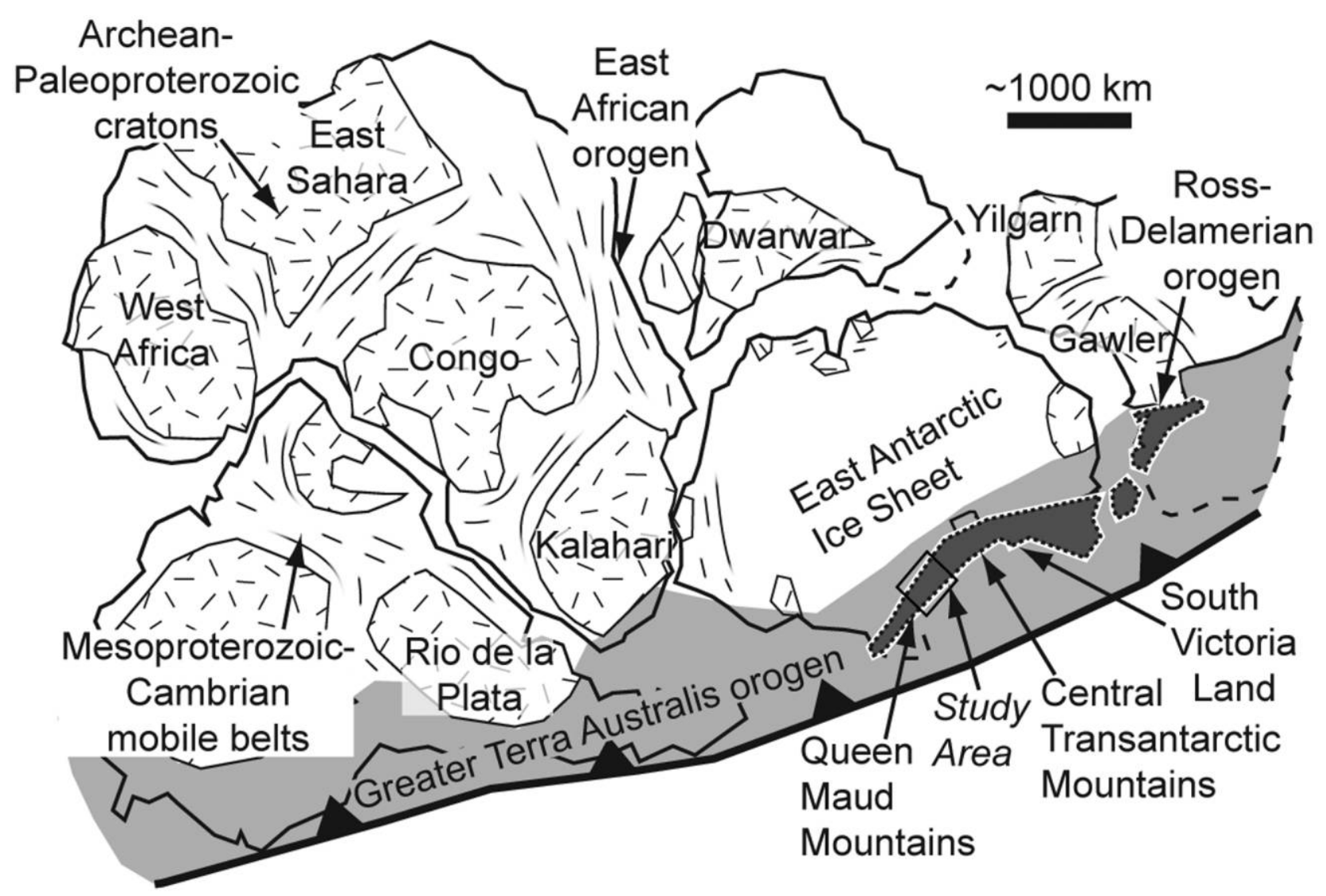

Figure 1. Gondwana reconstruction showing the Ross-Delamerian orogen within the greater latest Neoproterozoic to late Paleozoic Terra Australis orogen as well as the major Precambrian cratons and mobile belts of Gondwana. Figure modified from Paulsen et al. (2016b).

rocks of similar age is postulated to have seeded the oceans with the elements required for organisms to develop hard body parts (Squire et al. 2006). These rocks have been the subject of numerous field and petrographical studies (Stump 1995) as well as modern geochronologic and geochemical work (Encarnación and Grunow 1996; Goodge and Dallmeyer 1992, 1996; Goodge et al. 1993, 2001, 2002, 2004a, 2004b, 2012; Paulsen et al. 2013, 2015, 2016a, 2016b, 2017; Hagen-Peter et al. 2015, 2016; Hagen-Peter and Cottle 2016). Nevertheless, geochronologic studies have mostly been conducted on a reconnaissance basis throughout large sectors of the orogen, despite the fact that such data are important to help constrain the spatial-temporal patterns of magmatism related to the evolution of the Ross-Delamerian orogen (Borg and DePaolo 1991; Encarnación and Grunow 1996; Curtis et al. 2004; Squire and Wilson 2005; Goodge et al. 2012; Hagen-Peter et al. 2015; Hagen-Peter and Cottle 2016) and metamorphic-magmatic episodes associated with Gondwana assembly (Boger and Miller 2004; Cawood 2005; Boger 2011) and Iapetus rifting (Grunow et al. 1996b).
The intent of this article is to present new zircon $\mathrm{U}-\mathrm{Pb}$ geochronologic data for volcanic rocks that outcrop along the Shackleton and Liv Glaciers of the Queen Maud Mountains to better constrain the timing, extent, and relationship of magmatism, deposition, and deformation in this remote sector of the Ross orogenic belt (fig. 1). Throughout this article, we use the 2015 International Chronostratigraphic Chart time scale (Cohen et al. 2013 [updated]).

\section{Geology of the Queen Maud Mountains}

Early work in the Queen Maud Mountains indicated that the Ross Supergroup contained at least two distinct tectonostratigraphic packages known as the Beardmore and Liv Groups (fig. 2; Stump 1995). The Beardmore Group was considered to have an older (Neoproterozoic) depositional age and includes greenschist facies siliciclastic rocks known as the La Gorce, Duncan, and Party Formations (Laird et al. 1971; Stump 1981, 1982, 1995). The Liv Group was considered to have a younger depositional age (Cambrian) 


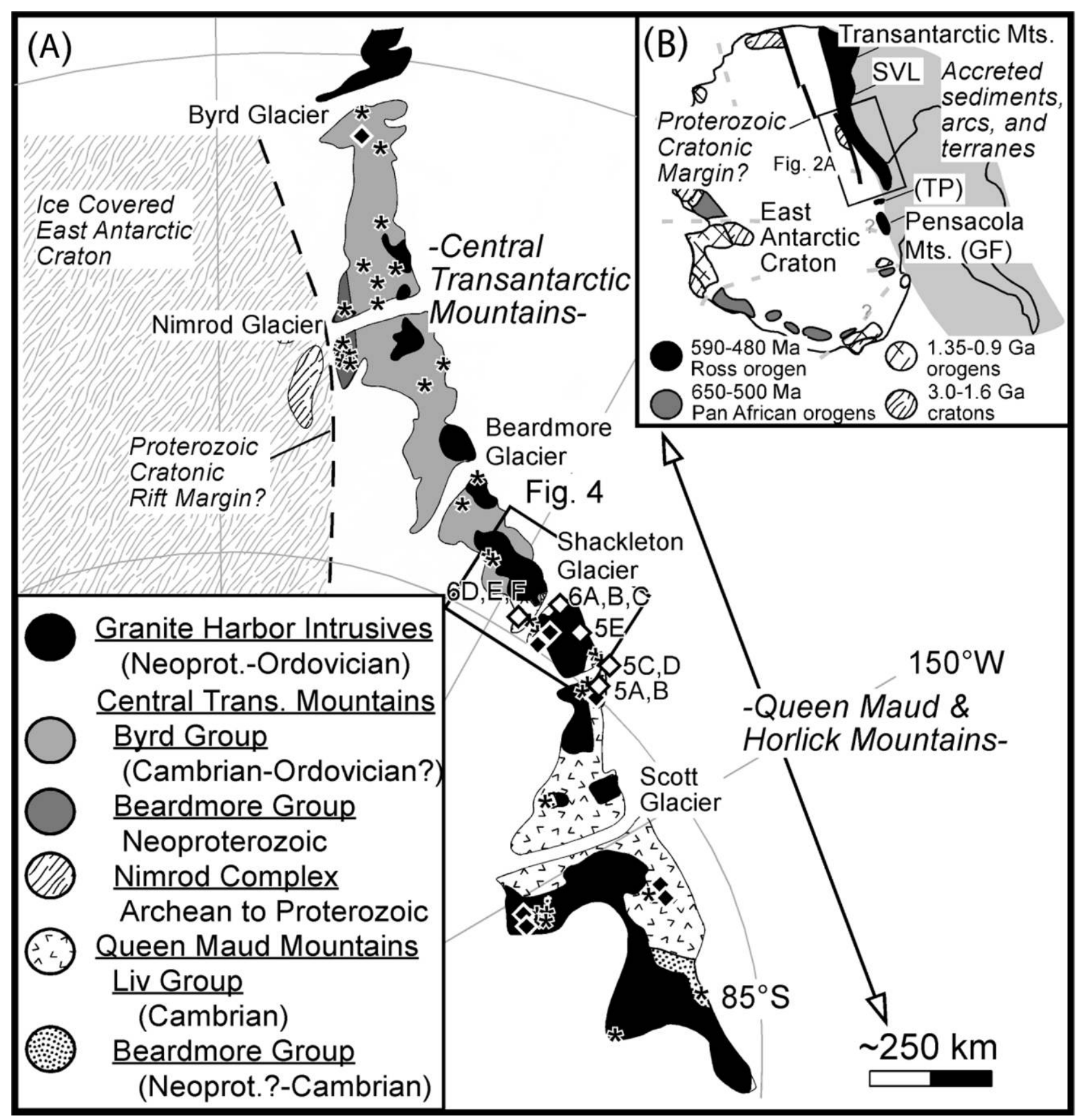

Figure 2. A, Simplified geologic map showing intrusive, sedimentary, and metamorphic basement rocks of the Ross orogen from the central Transantarctic Mountains to the south through the Queen Maud and Horlick Mountains. There are abundant volcanic rocks in early to middle Cambrian stratigraphic packages (i.e., the Liv Group) in the Queen Maud Mountains, whereas the early to middle Cambrian stratigraphic packages (i.e., the Byrd Group) in the central Transantarctic Mountains are practically devoid of volcanic rocks. The boundary separating the Liv Group from the Byrd Group occurs west of the Shackleton Glacier. Asterisks indicate approximate locations of detrital zircon samples analyzed by previous authors for the Queen Maud and central Transantarctic Mountains. Diamonds indicate approximate locations of volcanic samples analyzed in this article (white diamonds) and by previous authors (black diamonds) for the Queen Maud and central Transantarctic Mountains. Labels 5A-E and 6A-F correlate with localities of samples analyzed in this article and their age data shown in figures 5 and 6 . B, Locality of the Transantarctic Mountains (approximately the black area of the Ross orogen) as well as the area of the figure with respect to major crustal age provinces and the trace of the possible Proterozoic rift margin of East Antarctica. Figure compiled from Stump (1982), Borg and DePaolo (1994), Goodge (2007), and Goodge and Finn (2010). GF = Gambacorta Formation; Mts. = mountains; Neoprot. = Neoproterozoic; SVL = south Victoria Land; $\mathrm{TP}=$ Thiel Mountains porphyry; Trans. $=$ Transantarctic. 
and contains volcanic and volcaniclastic rocks interbedded with carbonate and siliciclastic rocks (Rowell and Rees 1989) that include the Wyatt, Ackerman, Leverett, Taylor, Fairweather, and Greenlee Formations (Stump 1995; Rowell et al. 1997; Rowell and Rees 1989; Wareham et al. 2001). More recent paleontological and geochronologic studies (as in fig. 3) have yielded late Neoproterozoic to Cambrian ages for sedimentary and volcanic rocks of the Liv and Beardmore Groups, indicating that rocks belonging to both units are at least in part temporal correlatives to the Cambrian Byrd Group (Shackleton Limestone and Douglas and Starshot Formations) in the central Transantarctic Mountains (fig. 3).

Intrusions of the Queen Maud batholith (McGregor 1965; Murtaugh 1969; Borg et al. 1990; Stump 1995) invade Ediacaran to Cambrian metasedimentary and metavolcanic rocks of the Beardmore and Liv Groups in the Queen Maud Mountains. Batholith intrusions range from granite to gabbro in composition and have isotopic patterns indicative of derivation from mantle and Precambrian basement sources (Borg et al. 1990; Borg and DePaolo 1991, 1994). Early K-Ar and Rb-Sr geochronology suggested that some intrusions and volcanic country rocks of the Queen Maud batholith crystallized and cooled as early as the late Proterozoic (Faure et al. 1979; Felder and Faure 1979), but many of these older ages suffered from large errors, possible excess $\mathrm{Ar}$, and open system behavior. More recent zircon U-Pb geochronology indicates that emplacement of intrusive and volcanic rocks primarily occurred after $535 \mathrm{Ma}$ (Encarnación and Grunow 1996; Van Schmus et al. 1997; Paulsen et al. 2013), and ${ }^{40} \mathrm{Ar}^{39} \mathrm{Ar}$ data indicate $\sim 500-475 \mathrm{Ma}$ metamorphic and igneous cooling (fig. 3; Grunow and Encarnación 2000a, 2000b; Paulsen et al. 2004, 2008, 2013).

Despite recent progress toward understanding the geochronology of tectonomagmatic events in the Queen Maud batholith, there are significant uncertainties about the timing of magmatism, deformation, and metamorphism in the broader Ross orogen because of the limited number of U-Pb age analyses over a relatively large region (Encarnación and Grunow 1996; Vogel et al. 2002). The paucity of age analyses is particularly problematic for understanding the correlation and tectonic significance of volcanic rocks hosted by the Queen Maud batholith. Although these volcanic rocks have been recognized since the early geologic exploration of the continental interior (McGregor 1965), their ages and correlation with each other and magmatic pulses along the Pacific-Gondwana margin (Encarnación and Grunow 1996; Goodge et al. 2012; Hagen-Peter and Cottle 2016; Hagen-Peter et al. 2016) remain poorly constrained.
The problems stemming from lack of age data are highlighted by U-Pb crystallization ages obtained from volcanic rocks of the Liv Group in the region of the Shackleton and Liv Glaciers (fig. 4). Van Schmus et al. (1997) reported $550 \pm 15$ and $516 \pm 6 \mathrm{Ma}$ zircon U-Pb crystallization ages for volcanic rocks of the Fairweather and Taylor Formations, respectively. The $\sim 550 \mathrm{Ma}$ crystallization age overlaps with the age of alkaline igneous rocks known from the south Victoria Land area of the Ross orogenic belt, such as the $551 \pm 4 \mathrm{Ma}$ age of syenite intrusions from the Skelton Glacier area (Rowell et al. 1993; Encarnación and Grunow 1996; Hagen-Peter and Cottle 2016) as well as the $545 \pm 5 \mathrm{Ma}$ intrusions from the central Transantarctic Mountains (Goodge et al. 1993, 2012). However, this $\sim 550 \mathrm{Ma}$ age for the Fairweather Formation apparently predates the oldest $(\sim 535 \mathrm{Ma})$ crystallization ages of rocks within the Queen Maud batholith (fig. 3). This older 550 Ma age for the Fairweather Formation assumes regional tectonic significance in the Ross orogenic belt because it could represent the oldest volcanic rock recognized in the Ross-Delamerian orogenic belt outside of $650 \mathrm{Ma}$ rhyolite clasts dated in south Victoria Land as well as mafic volcanic rocks associated with a 668 Ma gabbro intrusion, which are postulated to be related to earlier late Neoproterozoic rifting (Goodge et al. 2002; Cooper et al. 2011). More recently, $\mathrm{U}-\mathrm{Pb}$ age analyses of volcanic rocks of the Taylor Formation at Taylor Nunatak yielded a relatively more precise $505 \pm 1.5 \mathrm{Ma}$ crystallization age (Encarnación et al. 1999). This age overlaps crystallization ages of rocks within the Queen Maud batholith and depositional ages indicated by detrital zircon analyses of Liv Group sandstones (Paulsen et al. 2015, 2017), but it is the youngest volcanic rock recognized in the Ross-Delamerian orogenic belt outside of $\sim 500 \mathrm{Ma}$ volcanic rocks in the Thiel and Pensacola Mountains (the Thiel Mountains porphyry and the Gambacorta Formation in fig. 2b). This $\sim 500 \mathrm{Ma}$ age for the Taylor Formation is significantly younger than the $526 \pm 2$ to $516 \pm 6 \mathrm{Ma}$ crystallization ages (Encarnación and Grunow 1996; Van Schmus et al. 1997) yielded by other volcanic rocks of the Liv Group.

Apart from the three zircon ages from Liv Group samples mentioned above, there have been no other $\mathrm{U}-\mathrm{Pb}$ age analyses of the volcanic successions of the Liv Group in the area from the Shackleton Glacier to the Liv Glacier. Here we provide new crystallization ages of 11 deformed volcanic rocks of the Fairweather, Taylor, and Greenlee Formations (fig. 4), including two samples acquired from the Polar Rock Repository (those with PRR numbers) and nine from other collections. The new ages establish important 


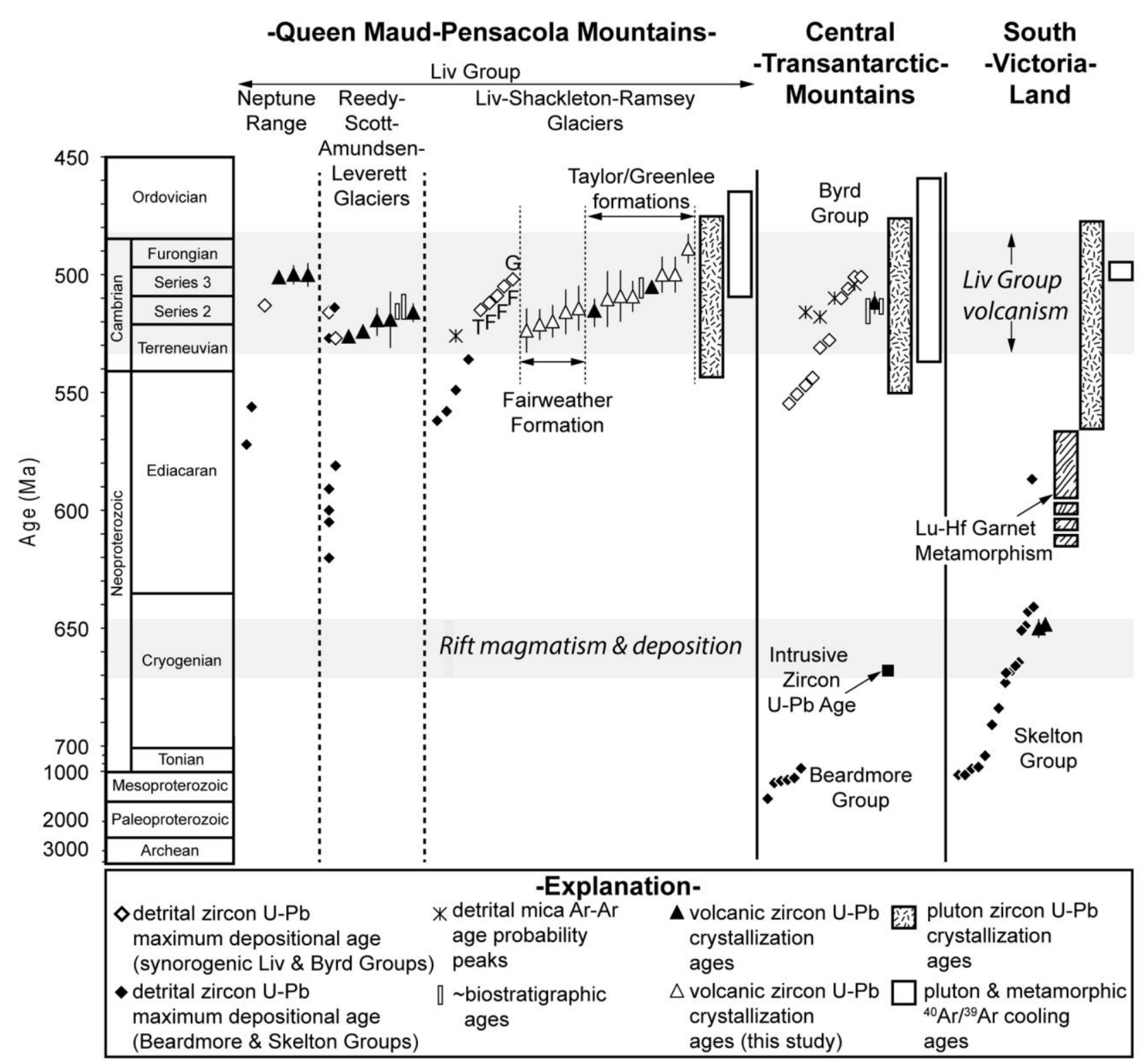

Figure 3. Diagram summarizing the available age constraints for the crystallization ages of volcanic and plutonic rocks, maximum depositional ages of siliciclastic rocks, and cooling ages of igneous and metamorphic rocks within the Queen Maud to Pensacola Mountains with respect to the central Transantarctic Mountains and south Victoria Land in the Ross orogen. Vertical black lines show errors on ages. Note the change in scale at $700 \mathrm{Ma}$. The Skelton Group in south Victoria Land includes the Koettlitz Group, following Gunn and Warren (1962) and Cook and Craw (2001). Ages are compiled from Goodge and Dallmeyer (1992, 1996), Rowell et al. (1992, 1993, 1997), Goodge et al. (1993, 2002, 2004a, 2004b, 2012), Hall et al. (1995), Millar and Storey (1995), Encarnación and Grunow (1996), Cooper et al. (1997), Van Schmus et al. (1997), Encarnación et al. (1999), Cox et al. (2000), Grunow and Encarnación (2000a, 2000b), Cook and Craw (2001), Allibone and Wysoczanski (2002), Mellish et al. (2002), Myrow et al. (2002), Read et al. (2002), Vogel et al. (2002), Curtis et al. (2004), Paulsen et al. (2004, 2008, 2013, 2015, 2017), Stump et al. (2004, 2006, 2007), Wysoczanski and Allibone (2004), Cottle and Cooper (2006a, 2006b), Talarico et al. (2007), Cooper et al. (2011), Hagen-Peter et al. $(2015,2016)$, and Martin et al. (2015). F = Fairweather Formation; $\mathrm{G}=$ Greenlee Formation; $\mathrm{T}=$ Taylor Formation. 


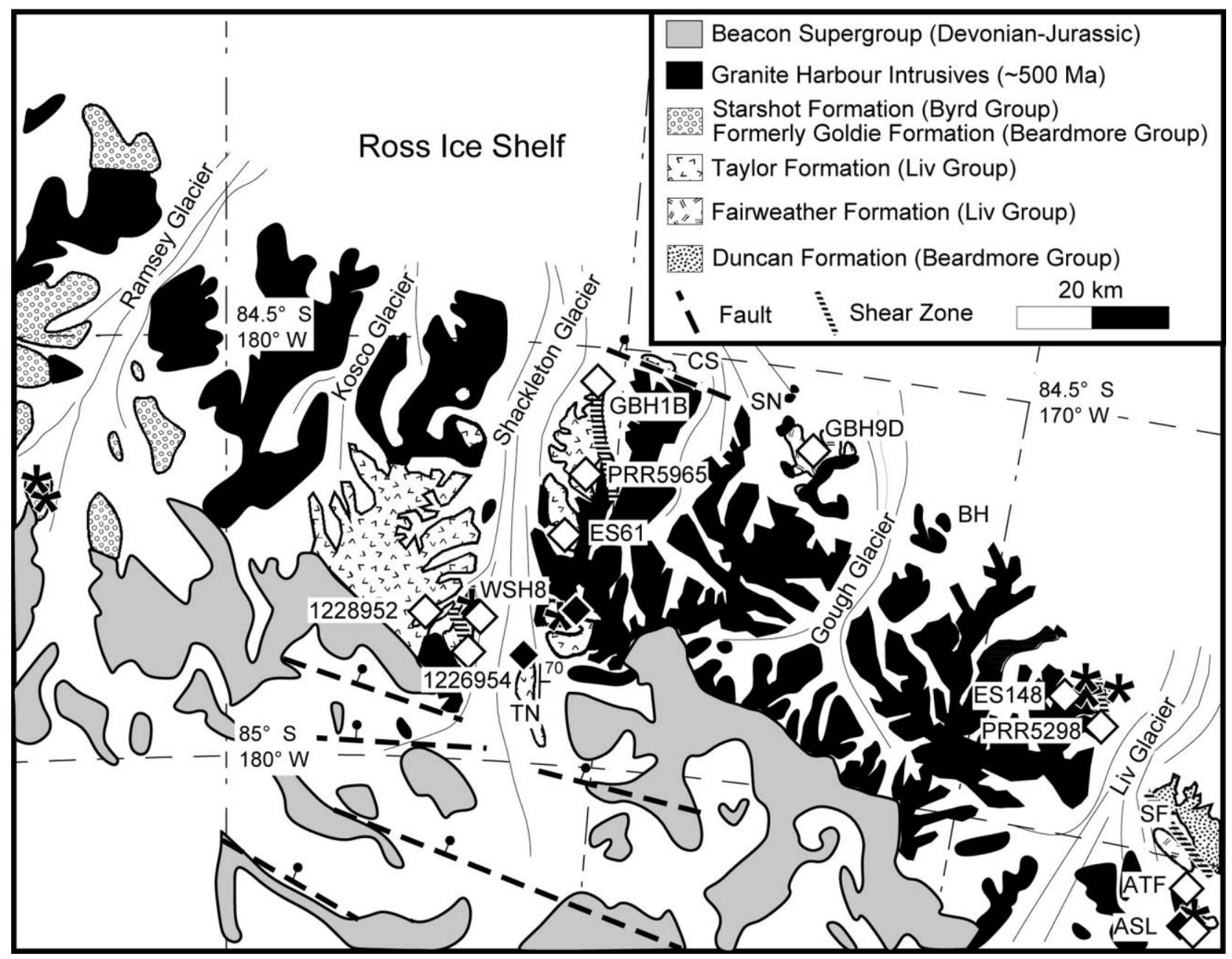

Figure 4. Simplified map showing the sample localities and geology in the Ramsey, Shackleton, and Liv Glacier areas (modified from Mirsky 1969). Diamonds show localities of volcanic rock samples analyzed herein (Fairweather Formation: ATF, ASL, PRR-5298, ES148, GBH9D; Taylor Formation: GBH1B, ES61, PRR-5965, 1226954, 1228952; Greenlee Formation: WSH8), and asterisks show locations of previous detrital zircon U-Pb age analyses reported in Paulsen et al. $(2015,2017)$. BH = Bravo Hills; $C S=$ Cape Surprise; SN = Sage Nunataks; SF = Spillway Fault; $T N=$ Taylor Nunatak.

correlations between major volcanic-volcaniclastic units in the area and provide limits to the timing of their deformation.

\section{U-Pb Methods}

Paulsen et al. (2008) describe the methods used for the separation and analysis of zircons from samples GBH9D and GBH1B. The methods used for the separation and analysis of zircons from the remaining nine samples are described below. Mineral concentrates were obtained from the samples by conventional mineral separation techniques. A split of these grains (generally 50-100 grains) was selected from the grains available and incorporated into a 1-inch epoxy mount together with fragments of Sri Lanka standard zircon. The mounts were sanded to a depth of $\sim 20 \mu$, polished, imaged, and cleaned prior to isotopic analysis.

U-Pb geochronology of zircons was conducted by laser ablation multicollector inductively coupled plasma mass spectrometry at the Arizona LaserChron Center (Gehrels et al. 2008). The analyses involve ablation of zircon with a New Wave/Lambda Physik DUV193 excimer laser (operating at a wavelength of $193 \mathrm{~nm}$ ) using a spot diameter of $35 \mu$. The ablated material is carried in helium into the plasma source of a GV Instruments IsoProbe device, which is equipped with a flight tube of sufficient width that $U$, $\mathrm{Th}$, and $\mathrm{Pb}$ isotopes are measured simultaneously. All measurements were made in static mode, using $10^{11} \Omega$ Faraday detectors for ${ }^{238} \mathrm{U},{ }^{232} \mathrm{Th},{ }^{208} \mathrm{~Pb}$, 
and ${ }^{206} \mathrm{~Pb}$; a $10^{12}-\Omega$ Faraday collector for ${ }^{207} \mathrm{~Pb}$; and an ion-counting channel for ${ }^{204} \mathrm{~Pb}$. Ion yields are $\sim 1.0 \mathrm{mV} / \mathrm{ppm}$. Each analysis consisted of one 12-s integration on peaks with the laser off (for backgrounds), twelve 1-s integrations with the laser firing, and a 30-s delay to purge the previous sample and prepare for the next analysis. Ablation pits are $\sim 12 \mu$ in depth.

For each analysis, the errors in determining ${ }^{206} \mathrm{~Pb} /$ ${ }^{238} \mathrm{U}$ and ${ }^{206} \mathrm{~Pb} /{ }^{204} \mathrm{~Pb}$ result in a measurement error of $\sim 1 \%-2 \%$ (at the $1 \sigma$ level) in the ${ }^{206} \mathrm{~Pb} /{ }^{238} \mathrm{U}$ age. The errors in measurement of ${ }^{206 \mathrm{~Pb}} /{ }^{207} \mathrm{~Pb}$ and ${ }^{206} \mathrm{~Pb} /{ }^{204} \mathrm{~Pb}$ also result in $\sim 1 \%-2 \%$ uncertainty (at the $1 \sigma$ level) in the ${ }^{207} \mathrm{~Pb} /{ }^{206} \mathrm{~Pb}$ age for grains that are older than $1000 \mathrm{Ma}$ but are substantially larger for younger grains due to low intensity of the ${ }^{207} \mathrm{~Pb}$ signal. Interpreted ages are based on ${ }^{206} \mathrm{~Pb} /{ }^{238} \mathrm{U}$ for grains younger than $1000 \mathrm{Ma}$ and on ${ }^{207} \mathrm{~Pb} /{ }^{206} \mathrm{~Pb}$ for grains older than $1000 \mathrm{Ma}$. This division at $1000 \mathrm{Ma}$ results from the increasing uncertainty of ${ }^{206} \mathrm{~Pb} /{ }^{238} \mathrm{U}$ ages and the decreasing uncertainty of ${ }^{207} \mathrm{~Pb} /{ }^{206} \mathrm{~Pb}$ ages as a function of age.

Common $\mathrm{Pb}$ correction is accomplished by using the measured ${ }^{204} \mathrm{~Pb}$ and assuming an initial $\mathrm{Pb}$ composition from Stacey and Kramers (1975; with uncertainties of 1.0 for ${ }^{206} \mathrm{~Pb} /{ }^{204} \mathrm{~Pb}$ and 0.3 for ${ }^{207} \mathrm{~Pb} /$ ${ }^{204} \mathrm{~Pb}$ ). Our measurement of ${ }^{204} \mathrm{~Pb}$ is unaffected by the presence of ${ }^{204} \mathrm{Hg}$ because backgrounds are measured on peaks (thereby subtracting any background ${ }^{204} \mathrm{Hg}$ and ${ }^{204} \mathrm{~Pb}$ ) and because very little $\mathrm{Hg}$ is present in the argon gas.

Interelement fractionation of $\mathrm{Pb} / \mathrm{U}$ is generally $\sim 20 \%$, whereas apparent fractionation of $\mathrm{Pb}$ isotopes is generally $\sim 2 \%$. In-run analysis (one or two every fifth measurement) of fragments of a large zircon crystal with a known age of $564.2 \pm 3.2 \mathrm{Ma}(2 \sigma$ error; Gehrels et al. 2008) is used to correct for this fractionation. The uncertainty resulting from the calibration correction is generally $1 \%-2 \%(2 \sigma)$ for both ${ }^{207} \mathrm{~Pb} /{ }^{206} \mathrm{~Pb}$ and ${ }^{206} \mathrm{~Pb} / 2{ }^{238} \mathrm{U}$ ages.

Concentrations of $U$ and $T h$ are calibrated relative to Sri Lanka zircon, which contains $\sim 518 \mathrm{ppm}$ of $U$ and $68 \mathrm{ppm}$ of Th.

The analytical data are reported in table S1 (available online). Uncertainties shown in this table are at the $1 \sigma$ level and include only measurement errors. Analyses that are $>15 \%$ discordant (by comparison of ${ }^{206} \mathrm{~Pb} /{ }^{238} \mathrm{U}$ and ${ }^{207} \mathrm{~Pb} / 206 \mathrm{~Pb}$ ages) or $>5 \%$ reverse discordant (shown in italics in table S1) are not considered further.

The inferred age is determined from the ${ }^{206} \mathrm{~Pb} /{ }^{238} \mathrm{U}$ age for analyses with a ${ }^{206} \mathrm{~Pb} /{ }^{238} \mathrm{U}$ age $<1000 \mathrm{Ma}$ and from the ${ }^{207} \mathrm{~Pb} /{ }^{206} \mathrm{~Pb}$ age for analyses with a ${ }^{206} \mathrm{~Pb} /{ }^{238} \mathrm{U}$ age $>1000 \mathrm{Ma}$. The resulting interpreted ages are shown in figures 5 and 6 on $\mathrm{Pb}^{*} / \mathrm{U}$ concordia dia- grams and weighted mean diagrams using the routines in Isoplot (Ludwig 2008). The weighted mean diagrams show the weighted mean (weighting according to the square of the internal uncertainties), the uncertainty of the weighted mean, the external (systematic) uncertainty that corresponds to the ages used, the final uncertainty of the age (determined by quadratic addition of the weighted mean and external uncertainties), and the MSWD of the data set. The systematic error includes contributions from the standard calibration, the age of the calibration standard, the composition of common $\mathrm{Pb}$, and $\mathrm{U}$ decay constants and in this data set range from $1.2 \%$ to $2.3 \%(2 \sigma)$.

\section{U-Pb Results}

The zircon grains yielded from all of these samples are subhedral to euhedral, with prismatic morphologies that display internal oscillatory, patchy, and unzoned domains, some of which surround xenocrystic cores. Ninety-nine percent ( $n=349$ of 351) of the U-Pb age analyses that meet acceptable concordance thresholds have $\mathrm{U} / \mathrm{Th}$ ratios of $<10$, suggesting that the zircons we analyzed primarily grew during igneous crystallization (Rubatto 2002; Hoskin and Schaltegger 2003), a result consistent with the presence of zircon grains with oscillatory zoned interiors and rational crystal faces (Corfu et al. 2003). The following presentation of the zircon U-Pb ages is separated by formation (the Fairweather Formation and the Taylor/Greenlee Formations).

Fairweather Formation. Seventy-four percent ( $n=153$ of 206$)$ of the U-Pb age analyses of zircons from five samples of the Fairweather Formation (ATF, ASL, PRR-5298, ES148, and GBH9D) met acceptable concordance thresholds. The cumulative zircon age distribution from all of the samples ranges from $1555 \mathrm{Ma}$ (Mesoproterozoic) to $423 \mathrm{Ma}$ (Silurian).

Samples ATF and ASL were collected from localities to the east of the Liv Glacier at Mount Fairweather, where Stump (1985) reported interbedded volcanic and siliciclastic rocks belonging to the Fairweather Formation (fig. 4). Sample ATF is a metafelsite that comes from the 39-m-thick unit from the bottom of section 3 for the eastern ridge of Mount Fairweather. A weighted mean ${ }^{206} \mathrm{~Pb} /{ }^{238} \mathrm{U}$ age of $515 \pm 9 \mathrm{Ma}$ from a concordant set of analyses is considered to be the age of igneous crystallization for sample ATF (fig. 5A). One discordant zircon age analysis yields a $423 \mathrm{Ma}$ age, which is younger than the rock's crystallization age and is presumably due 

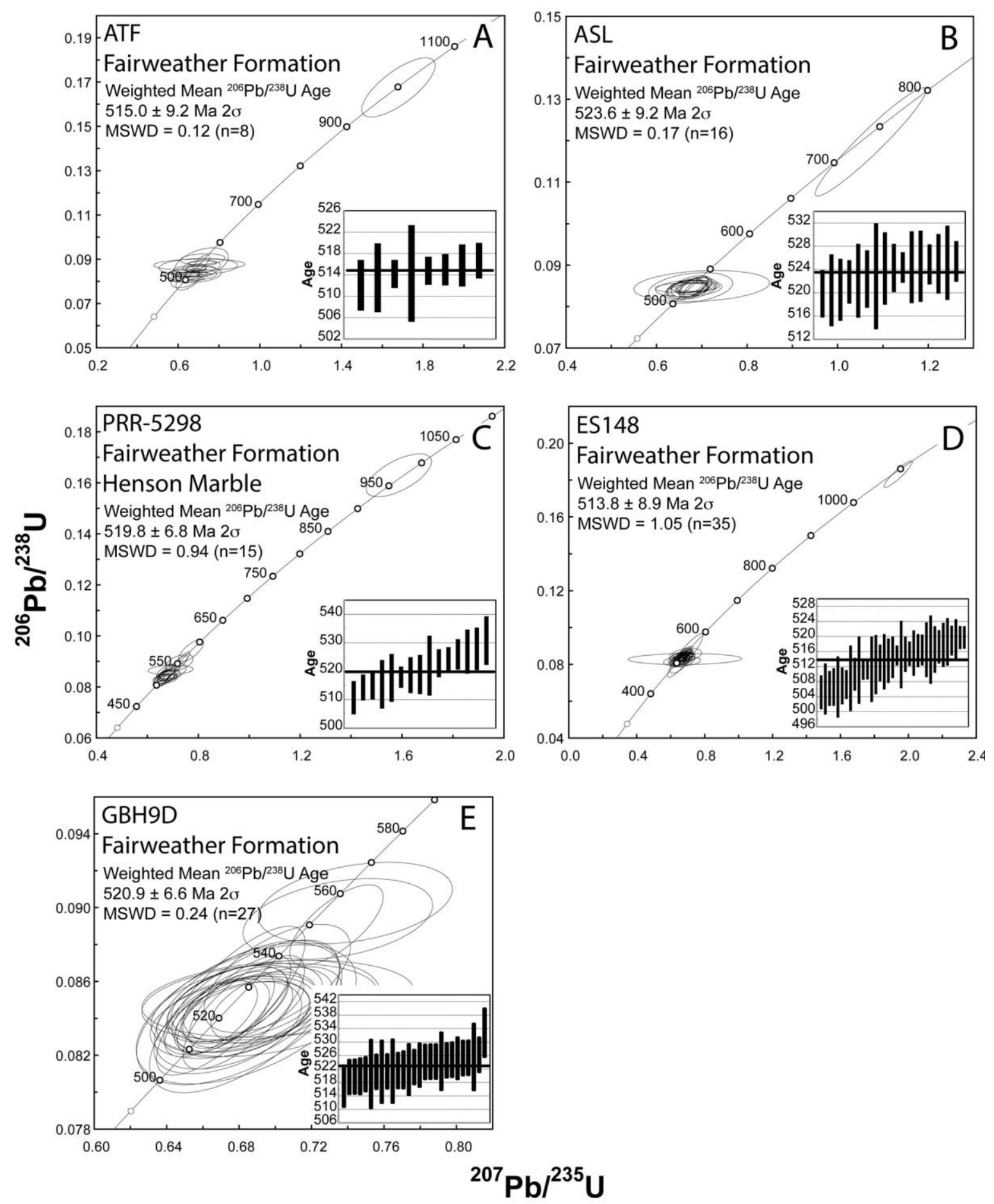

Figure 5. Concordia diagrams of zircon U-Pb data and weighted mean age plots of individual analyses for Fairweather Formation samples ATF $(A)$, ASL $(B)$, PRR-5298 $(C)$, ES148 $(D)$, and GBH9D $(E)$. Error bars are $1 \sigma$ from inferred U-Pb ages $\left({ }^{206} \mathrm{~Pb} /{ }^{238} \mathrm{U}\right.$ age for samples younger than $1000 \mathrm{Ma}$ and ${ }^{207} \mathrm{~Pb} /{ }^{206} \mathrm{~Pb}$ age for samples older than $\left.1000 \mathrm{Ma}\right)$. Data error ellipses are $2 \sigma$. 

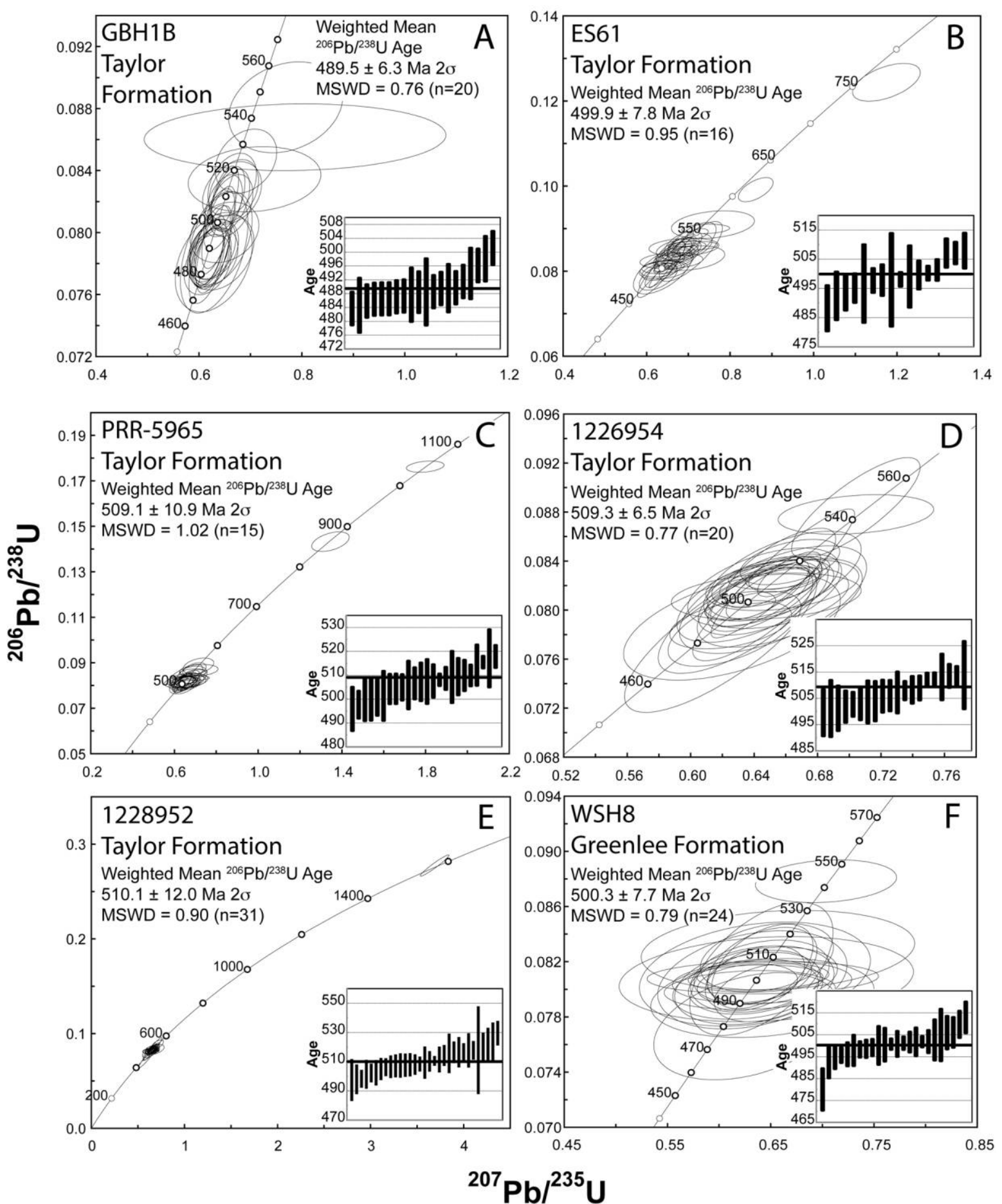

Figure 6. Concordia diagrams of zircon U-Pb data and weighted mean age plots of individual analyses for Taylor Formation samples GBH1B $(A)$, ES61 $(B)$, PRR-5965 (C), $1226954(D)$, and $1228952(E)$ and for Greenlee Formation sample WSH8 $(F)$. Error bars are $1 \sigma$ from inferred $\mathrm{U}-\mathrm{Pb}$ ages $\left({ }^{206} \mathrm{~Pb} /{ }^{238} \mathrm{U}\right.$ age for samples younger than $1000 \mathrm{Ma}$ and ${ }^{207} \mathrm{~Pb} /{ }^{206} \mathrm{~Pb}$ age for samples older than $1000 \mathrm{Ma}$ ). Data error ellipses are $2 \sigma$. 
to $\mathrm{Pb}$ loss. Sample ASL is a metafelsite that comes from a small spur that extends to the northeast from near the summit of Mount Fairweather, which is the same sample locality as the volcanic rock sample (ASJ) that yielded an upper intercept discordia age of $550 \pm 15 \mathrm{Ma}$ (Van Schmus et al. 1997). A weighted mean ${ }^{206} \mathrm{~Pb} /{ }^{238} \mathrm{U}$ age of $524 \pm 9 \mathrm{Ma}$ from a concordant set of analyses is considered to be the age of igneous crystallization for sample ASL (fig. 5B).

Samples PRR-5298 and ES148 were collected from localities to the west of the Liv Glacier at Mount Fairweather (fig. 4; Stump 1985; Grunow et al. 1996a). Sample PRR-5298 comes from a 10-m-thick white micaceous rock with mafic spots that was described as a metamorphosed tuff within marble collected from the Henson Marble Member of the Fairweather Formation just above the level of the Liv Glacier at the Tusk. It likely has a tuff-volcaniclastic protolith, which is strongly supported by the presence of apparently unabraded, euhedral, oscillatory-zoned crystals that occur within the zircon split. A weighted mean ${ }^{206} \mathrm{~Pb} /{ }^{238} \mathrm{U}$ age of $520 \pm 7 \mathrm{Ma}$ from a concordant set of analyses is considered to be the age of igneous crystallization for sample PRR-5298 (fig. 5C). Sample ES148 is a metafelsite collected from interbedded volcanic and siliciclastic rocks of the Fairweather Formation at Mount Henson. A weighted mean ${ }^{206} \mathrm{~Pb} /{ }^{238} \mathrm{U}$ age of $514 \pm 9 \mathrm{Ma}$ from a concordant set of analyses is considered to be the age of igneous crystallization for sample ES148 (fig. 5D).

Sample GBH9D is a quartz-rich volcanic breccia collected from deformed metavolcanic rocks and marbles at a small nunatak located to the east of Polaris Peak (fig. 4). A weighted mean ${ }^{206} \mathrm{~Pb} /{ }^{238} \mathrm{U}$ age of $521 \pm 7 \mathrm{Ma}$ from a concordant set of analyses is considered to be the age of igneous crystallization for sample GBH9D (fig. 5E). Three concordant zircon age analyses yield 557-550 Ma ages, which presumably reflect inheritance.

The $524 \pm 9$ to $514 \pm 9$ Ma volcanic crystallization ages for our samples of the Fairweather Formation are consistent with an early Cambrian age (possibly late Terreneuvian or Series 2 from 521 to $509 \mathrm{Ma}$ ) suggested by a solitary probable archaeocyathan found at Mount Fairweather in the Henson Marble Member (Grunow et al. 1996a) as well as 512-504 Ma maximum depositional ages indicated by detrital zircon age populations for the Fairweather Formation (Paulsen et al. 2015, 2017).

Taylor/Greenlee Formations. Eighty percent $(n=$ 217 of 272) of the U-Pb age analyses of zircons from the Taylor Formation (GBH1B, ES61, PRR-5965, 1226954, and 1228952) and the Greenlee Formation (WSH8) met acceptable concordance thresholds. The cumulative zircon age distribution from all of the samples range from $1042 \mathrm{Ma}$ (Mesoproterozoic) to $480 \mathrm{Ma}$ (early Ordovican).

Samples GBH1B, ES61, and PRR-5965 were collected from localities to the east of lower stretches of the Shackleton Glacier (fig. 4). Sample GBH1B is a protomylonitic rhyolite porphyry collected from brightly colored pink, red, and green mylonitic volcanic rocks of the Taylor Formation at Nilsen Peak along the Massam Glacier near the Transantarctic Mountain front. A weighted mean ${ }^{206} \mathrm{~Pb} /{ }^{238} \mathrm{U}$ age of $490 \pm 6 \mathrm{Ma}$ from a concordant set of analyses is considered to be the age of igneous crystallization for sample GBH1B (fig. 6A). Samples ES61 and PRR5965 were collected from interbedded volcanic and siliciclastic rocks of the Taylor Formation at Mount Wendland. Sample ES61 is a metafelsite with a definite welded shard structure with spherulites. A weighted mean ${ }^{206} \mathrm{~Pb} /{ }^{238} \mathrm{U}$ age of $500 \pm 6 \mathrm{Ma}$ from a concordant set of analyses is considered to be the age of igneous crystallization for sample ES61 (fig. 6B). Sample PRR-5965 is a dacite cobble collected from a sheared monomictic conglomerate, which likely represents locally eroded volcanic material from interbedded Taylor Formation volcanic rocks, considering its monomictic character. A weighted mean ${ }^{206} \mathrm{~Pb} /{ }^{238} \mathrm{U}$ age of $509 \pm 11 \mathrm{Ma}$ from a concordant set of analyses is considered to be the age of igneous crystallization for sample PRR-5965 (fig. 6C), which also represents a maximum depositional age for the Taylor Formation that is consistent with the $500 \mathrm{Ma}$ crystallization age of sample ES61 from Mount Wendland.

Samples 1226954, 1228952, and WSH8 were collected from localities on the west flank of upper stretches of the Shackleton Glacier (fig. 4). Sample 1226954 is a protomylonitic felsite porphyry collected from brightly colored pink and green volcanic outcrops visible on the high slopes of Mount Greenlee at Taylor Nunatak. A weighted mean ${ }^{206} \mathrm{~Pb} /{ }^{238} \mathrm{U}$ age of $509 \pm 6 \mathrm{Ma}$ from a concordant set of analyses is considered to be the age of igneous crystallization for sample 1226954 (fig. 6D). Samples 1228952 and WSH8 were collected from interbedded volcanic and siliciclastic rocks of the Taylor Formation along the Shackleton Glacier at Mount Greenlee. Sample 1228952 is a metafelsite collected from southern exposures of the Mount Greenlee sequence to the north of granites that intrude the sequence. A weighted mean ${ }^{206} \mathrm{~Pb} /{ }^{238} \mathrm{U}$ age of $510 \pm 12 \mathrm{Ma}$ from a concordant set of analyses is considered to be the age of igneous crystallization for sample 1226952 (fig. 6E). Sample WSH8 is a massive to crudely layered plagioclase crystal tuff of the Greenlee Formation that alternates with black argillite and is overlain by a massive mafic unit. A weighted mean ${ }^{206} \mathrm{~Pb} /{ }^{238} \mathrm{U}$ age of $500 \pm 8 \mathrm{Ma}$ from a concordant set of analyses is 
considered to be the age of igneous crystallization for sample WSH8 (fig. 6F).

The $510 \pm 12$ to $490 \pm 6 \mathrm{Ma}$ volcanic crystallization ages yielded by the Taylor and Greenlee Formations are consistent with U-Pb dates and paleontological (trilobite) data from felsic volcanic rocks at Lubbock Ridge (516 $\pm 6 \mathrm{Ma}$ U-Pb crystallization age; Van Schmus et al. 1997) and carbonate units (Cambrian, Series 3) interbedded with volcanic rocks (505 $\pm 1.5 \mathrm{Ma}$ U-Pb crystallization age) at Taylor Nunatak (Encarnación et al. 1999). The Taylor and Greenlee Formation crystallization ages are also consistent with 515 and 502 Ma maximum depositional ages indicated by detrital zircon age populations for the Taylor and Greenlee Formations at Lubbock Ridge and Mount Greenlee, respectively (Paulsen et al. 2015, 2017).

\section{Discussion and Conclusions}

The $524 \pm 9$ to $490 \pm 6 \mathrm{Ma}$ U-Pb crystallization ages reported in this article provide new constraints on the depositional ages of the volcanic and associated interbedded metasedimentary rocks that comprise the Fairweather and Taylor/Greenlee Formations of the Liv Group in the Shackleton to Liv Glacier area. These and the previously published Taylor Formation crystallization ages indicate that the Fairweather Formation (533-505 Ma) is likely to be early to middle Cambrian in age (Terreneuvian to early Series 3) and that the Taylor/Greenlee Formations (522-483 Ma) are middle to late Cambrian (Series 2 to Furongian) in age. These ages, taken together with the biostratigraphic and detrital mineral age data shown in figure 3, confirm the temporal correlation of portions of the Taylor, Greenlee, and Fairweather Formations, as previously suggested by Stump (1985) and Wade and Cathey (1986).

In other regions like the central Transantarctic Mountains, the depositional age of synorogenic sediments of the Ross orogen is bracketed by detrital mineral ages, metamorphic cooling ages, and crosscutting igneous ages that allow Cambrian to earliest Ordovician deposition (Goodge et al. 2004a). By contrast, the 533-483 Ma ages (Cambrian, Terreneuvian to Series 2) from syndepositional volcanic units from which our samples were collected provide important new data that tightly constrain deposition in this sector of the Ross orogen to primarily lie within the Cambrian. On a regional scale, the 533-483 Ma volcanic ages overlap with biostratigraphic, U-Pb volcanic crystallization, and maximum depositional ages (based on detrital zircon U-Pb ages) for interbedded sedimentary and volcanic rocks found elsewhere in the Ross orogen (fig. 3) as well as volcanic rock successions in Australia and New Zealand (Squire and Wilson 2005). The 533-483 Ma volcanic crystallization ages are significantly younger than the poorly defined discordia upper intercept age of $550 \pm 15 \mathrm{Ma}$ for a volcanic rock from the Fairweather Formation at Mount Fairweather (Van Schmus et al. 1997), eliminating these interbedded metavolcanic and metasedimentary rocks as candidates for Precambrian cratonic crust and the oldest volcanic rocks exposed in the Ross-Delamerian orogenic belt. The 533-483 Ma crystallization ages therefore preclude correlation of our samples with $\sim 670-650 \mathrm{Ma}$ synrift sedimentary rocks of the Beardmore Group in the central Transantarctic Mountains and the Skelton Group of south Victoria Land (fig. 3; Goodge et al. 2002; Cooper et al. 2011).

The 533-505 Ma volcanic crystallization ages of Liv Group volcanic rocks indicate deposition concomitant with the younger emplacement of $\sim 535$ $490 \mathrm{Ma}$ plutonic rocks found in the Queen Maud batholith (Queen Maud Mountains) and other Cambrian igneous rocks along the early Paleozoic PacificGondwana margin (fig. 3). Figure 7 shows a relative age probability diagram for all zircon U-Pb crystallization ages obtained for volcanic and plutonic rocks in this study and previous studies (Encarnación and Grunow 1996; Van Schmus et al. 1997; Vogel et al. 2002; Paulsen et al. 2008, 2013) for the Queen Maud batholith. The probability analysis shows a primary $521 \mathrm{Ma}$ age probability peak for the crystallization ages of igneous rocks. The zircon U-Pb igneous crystallization ages reported herein provide important new evidence for an early Cambrian (Terreneuvian to Series 2) flare up of magmatism in the Queen Maud batholith sector of the Ross orogen, which overlaps in age with 565-492 Ma magmatism in south Victoria Land (Hagen-Peter et al. 2015; Hagen-Peter and Cottle 2016) and 545-485 Ma magmatism in the central Transantarctic Mountains (Goodge et al. 2012).

The new crystallization ages reported in this article add substantially to our understanding of the age of magmatism in the Queen Maud batholith, thereby warranting an examination of its relation to sandstone provenance in the region. Importantly, the probability age distribution and peaks yielded by zircon $\mathrm{U}-\mathrm{Pb}$ igneous crystallization ages in the Queen Maud Mountains (fig. 7A) are similar to the youngest detrital zircon age probability peaks found in siliciclastic rocks from this area, suggesting that siliciclastic components of these successions mark the deposition of sedimentary material associated with, and derived from, arc-related rocks of the Ross orogen (Stump 1995; Encarnación and Grunow 1996; Myrow et al. 2002; Goodge et al. 2004b; Paulsen et al. 2015). The older 638,608 , and $563 \mathrm{Ma}$ detrital zircon 


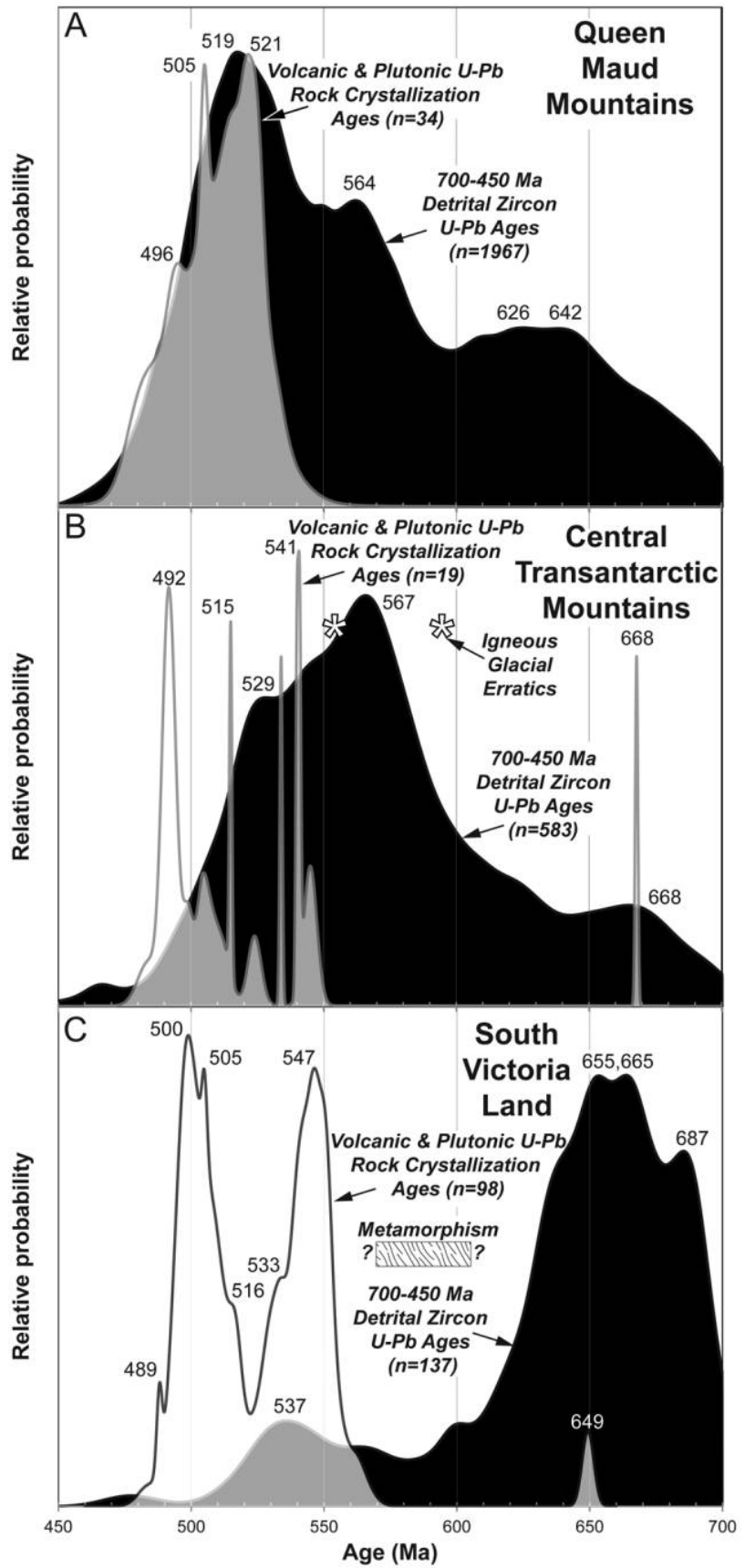

Figure 7. Stacked relative age probability diagrams (Ludwig 2008) for U-Pb igneous crystallization ages and detrital zircon ages falling within the 700-450 Ma time period from the Queen Maud Mountains $(A)$, central Transantarctic Mountains $(B)$, and south Victoria Land $(C)$ sectors of the Ross orogen. These probability curves take each age and its normally distributed uncertainty (for measurement error only) and sum them into a single curve. Asterisks in $B$ show ages of igneous glacial erratics reported in Goodge et al. (2012). Detrital zircon ages are compiled for the Liv and Beardmore Groups $(A)$ from Stump et al. (2007) and Paulsen et al. $(2015,2017)$; for the Byrd Group $(B)$ from Goodge et al. (2002, 2004b) and Paulsen et al. (2017); and for the Skelton age peaks yielded by siliciclastic rocks of the Queen Maud Mountains might reflect erosion of unexposed igneous rocks along the Pacific-Gondwana margin (Goodge et al. 2004b) or the interior of the East Antarctic craton. For example, in the central Transantarctic Mountains, magmatic crystallization ages also overlap with $<545 \mathrm{Ma}$ detrital zircon age populations yielded by synorogenic Byrd Group sandstones (fig. $7 B$ ). Similar older detrital zircon ages have also been found in these sandstones (Goodge et al. 2004b), where glacial clasts with 590-554 Ma crystallization ages suggest the presence of older unexposed igneous rocks (Goodge et al. 2012). In south Victoria Land, 560-488 Ma igneous rocks do not appear to be sources for the older detrital zircons that have been found to dominate Skelton Group sandstones, which were apparently deformed and metamorphosed prior to igneous intrusion (Hagen-Peter and Cottle 2016; Hagen-Peter et al. 2016). However, Skelton Group sediment appears to have been derived from older igneous rocks, of which local exposures occurring in south Victoria Land and the central Transantarctic Mountains have yielded 668-650 Ma ages. It is also possible that similar age populations are at least in part derived from long-distance transport from Dronning Maud Land (Jacobs 1999) or the East African orogen (Squire et al. 2006).

The $490 \mathrm{Ma}$ (GBH1B) crystallization age for our deformed Taylor Formation volcanic sample from Nilsen Peak overlaps with similar age plutonic rocks found throughout the orogen, some of which in the Queen Maud Mountains are also deformed (Paulsen et al. 2008, 2013). This sample is also similar in age to 497-482 Ma U-Pb crystallization ages yielded by clasts of rhyolite porphyry and tuff found in the basal conglomerates belonging to the Devonian (post-Ross orogen) Taylor Group of the Beacon Supergroup in south Victoria Land (Wysoczanski et al. 2003). The $490 \mathrm{Ma}(\mathrm{GBH} 1 \mathrm{~B})$ crystallization age assumes regional significance in the Ross orogenic belt because it represents the youngest in situ volcanic rock yet iden-

Group (C) from Stump et al. (2007), Cooper et al. (2011), and Paulsen et al. (2017). Volcanic and plutonic U-Pb crystallization ages are compiled from data presented in this article as well as Goodge et al. $(1993,2004 b, 2012)$, Rowell et al. (1993), Hall et al. (1995), Encarnación and Grunow (1996), Cooper et al. (1997), Van Schmus et al. (1997), Encarnación et al. (1999), Cox et al. (2000), Cook and Craw (2001), Allibone and Wysoczanski (2002), Mellish et al. (2002), Read et al. (2002), Vogel et al. (2002), Stump et al. (2004, 2006), Wysoczanski and Allibone (2004), Cottle and Cooper (2006a, 2006b), Read (2010), Cooper et al. (2011), Paulsen et al. (2013, 2016c), Hagen-Peter et al. (2015), Martin et al. (2015), and Hagen-Peter and Cottle (2016). 
tified within the Ross orogen and therefore provides important new evidence for Cambrian (Furongian) or younger deformation in this sector of the range.

The majority of ${ }^{40} \mathrm{Ar} /{ }^{39} \mathrm{Ar}$ mineral cooling ages for metamorphic and plutonic rocks of the Queen Maud batholith range from $\sim 502$ to $473 \mathrm{Ma}$ and therefore broadly overlap with this phase of magmatism (fig. 3; Grunow and Encarnación 2000b; Paulsen et al. 2004, 2008). The timing of this magmatic and orogenic cooling phase shows remarkable overlap with the emplacement of undeformed intrusions, orogenic cooling, and exhumation that occurred after $\sim 500 \mathrm{Ma}$ along the length of the Ross orogen and its northern extension, the Delamerian orogen in Australia (Borg et al. 1990; Goodge et al. 1991, 2004a, 2012; Goodge and Dallmeyer 1992, 1996; Stump 1995; Encarnación and Grunow 1996; Turner et al. 1996; Foster and Gray 2000; Allibone and Wysoczanski 2002; Foster et al. 2005; Squire and Wilson 2005; Foden et al. 2006; Paulsen et al. 2007; Talarico et al. 2007; Rocchi et al. 2011; HagenPeter and Cottle 2016; Hagen-Peter et al. 2016). This orogenic phase might have been associated in part with a geodynamic change to extension along the Gondwana margin that was fostered by rollback of the subducting slab with possible influences from lithospheric delamination (Turner et al. 1996; Foster and Gray 2000; Wareham et al. 2001; Foden et al.
2006; Rocchi et al. 2011). Indeed, orogenic collapse provides an attractive tentative model for the development of shear zones observed to crosscut Taylor Formation volcanic rocks in the Nilsen Peak (sample GBH1B) and Mount Greenlee (samples 1226954 and 1228952) areas in the Shackleton Glacier region (Stump 1985; Paulsen et al. 2004), where highangle dips and steeply plunging mineral stretching lineations in the volcanic rocks are consistent with the structural orientations expected during crustal extension.

\section{A C K N O W LEDGMENTS}

This work was funded by National Science Foundation (NSF) grant OPP-9317673 to A. M. Grunow, NSF grant OPP-0835480 to T. S. Paulsen, NSF grant OPP-9726104 to J. Encarnación, and the EAA/C. R. Meyer and Edward Penson endowed professorships to T. S. Paulsen. We thank J. Goodge, D. Foster, and J. Veevers for helpful reviews that improved the manuscript as well as M. Roberts for his assistance in the field. Samples PRR-5298 and PRR-5965 came from the Polar Rock Repository, Byrd Polar and Climate Research Center, Ohio State University (doi:10.7289/V5RF5S18). The Arizona LaserChron Center is supported by NSF grant EAR-0443387.

\section{REFERENCES CITED}

Allibone, A., and Wysoczanski, R. 2002. Initiation of magmatism during the Cambro-Ordovician Ross Orogeny in southern Victoria Land, Antarctica. Geol. Soc. Am. Bull. 114:1007-1018. doi:10.1130/0016-7606(2002) $114<1007$.

Barrett, P. J. 1991. The Devonian to Jurassic Beacon Supergroup of the Transantarctic Mountains and correlatives in other parts of Antarctica. In Tingey, R. J., ed. The geology of Antarctica. Oxford, Clarendon, p. 120152.

Boger, S. D. 2011. Antarctica-before and after Gondwana. Gondwana Res. 19:335-371. doi:10.1016/j.gr.2010.09 .003 .

Boger, S. D., and Miller, J. M. 2004. Terminal suturing of Gondwana and the onset of the Ross-Delamerian Orogeny: the cause and effect of an early Cambrian reconfiguration of plate motions. Earth Planet. Sci. Lett. 219:35-48. doi:10.1016/S0012-821X(03)00692-7.

Borg, S. G., and DePaolo, D. J. 1991. A tectonic model of the Antarctic Gondwana margin with implications for southeastern Australia: isotopic and geochemical evidence. Tectonophysics 196:339-358. doi:10.1016/0040 -1951(91)90329-Q.
1994. Laurentia, Australia, and Antarctica as a Late Proterozoic supercontinent: constraints from isotopic mapping. Geology 22:307-310. doi:10.1130 /0091-7613(1994)022<0307:LAAAAA >2.3.CO;2.

Borg, S. G.; Depaolo, D. J.; and Smith, B. M. 1990. Isotopic structure and tectonics of the central Transantarctic mountains. I. Geophys. Res. 95:6647-6667. doi:10.1029 /JB095iB05p06647.

Cawood, P. A. 2005. Terra Australis orogen: Rodinia breakup and development of the Pacific and Iapetus margins of Gondwana during the Neoproterozoic and Paleozoic. Earth-Sci. Rev. 69:249-279. doi:10.1016 /j.earscirev.2004.09.001.

Cohen, K. M.; Finney, S. C.; Gibbard, P. L.; and Fan, J.-X. 2013 (updated). The ICS International Chronostratigraphic Chart. Episodes 36:199-204. doi:10.1111 /j.1502-3931.1980.tb01026.x.

Cook, Y. A., and Craw, D. 2001. Amalgamation of disparate crustal fragments in the Walcott Bay-Foster Glacier area, south Victoria Land, Antarctica. N. Z. I. Geol. Geophys. 44:403-416. doi:10.1080/00288306.2001.9514947.

Cooper, A. F.; Maas, R.; Scott, J. M.; and Barber, A. J. W. 2011. Dating of volcanism and sedimentation in the 
Skelton Group, Transantarctic Mountains: implications for the Rodinia-Gondwana transition in southern Victoria Land, Antarctica. Bull. Geol. Soc. Am. 123:681-702. doi:10.1130/B30237.1.

Cooper, A. F.; Worley, B. A.; Armstrong, R. A.; and Price, R. C. 1997. Synorogenic alkaline and carbonatitic magmatism in the Transantarctic Mountains of south Victoria Land, Antarctica. In Ricci, C. A., ed. The Antarctic region: geological evolution and processes. Siena, Terra Antarctica, p. 191-202.

Corfu, F.; Hanchar, J. M.; Hoskin, P. W. O.; and Kinny, P. 2003. Atlas of zircon textures. Rev. Mineral. Geochem. 53:469-500. doi:10.2113/0530469.

Cottle, J. M., and Cooper, A. F. 2006a. The Fontaine Pluton: an early Ross Orogeny calc-alkaline gabbro from southern Victoria Land, Antarctica. N. Z. I. Geol. Geophys. 49:177-189.

- 2006b. Geology, geochemistry, and geochronology of an A-type granite in the Mulock Glacier area, southern Victoria Land, Antarctica. N. Z. I. Geol. Geophys. 49:191-202. doi:10.1080/00288306.2006.9515159.

Cox, S. C.; Parkinson, D. L.; Allibone, A. H.; and Cooper, A. F. 2000. Isotopic character of Cambro-Ordovician plutonism, southern Victoria Land, Antarctica. N. Z. I. Geol. Geophys. 43:501-520.

Curtis, M. L.; Millar, I. L.; Storey, B. C.; and Fanning, M. 2004. Structural and geochronological constraints of early Ross orogenic deformation in the Pensacola Mountains, Antarctica. Bull. Geol. Soc. Am. 116:619636. doi:10.1130/B25170.1.

Encarnación, J., and Grunow, A. 1996. Changing magmatic and tectonic styles along the paleo-Pacific margin of Gondwana and the onset of early Paleozoic magmatism in Antarctica. Tectonics 15:1325-1341. doi:10.1029/96TC01484.

Encarnación, J.; Rowell, A. J.; and Grunow, A. M. 1999. A U-Pb age for the Cambrian Taylor Formation, Antarctica: implications for the Cambrian time scale. I. Geol. 107:497-504. doi:10.1086/314361.

Faure, G.; Eastin, R.; Ray, P. T.; Mclelland, D.; and Shultz, C. H. 1979. Geochronology of igneous and metamorphic rocks, central Transantarctic Mountains. Calcutta, Hindustan Publishing.

Felder, R. P., and Faure, G. 1979. Investigation of an anomalous date for Lonely Ridge granodiorite, Nilsen Plateau, Transantarctic Mountains. Antarct. J. U.S. 14:24.

Fitzgerald, P. G.; Sandiford, M.; Barrett, P. J.; and Gleadow, A. J. W. 1986. Asymmetric extension associated with uplift and subsidence in the Transantarctic Mountains and Ross embayment. Earth Planet. Sci. Lett. 81:67-78. doi:10.1016/0012-821X|86)90101-9.

Foden, J.; Elburg, M. A.; Dougherty-Page, J.; and Burtt, A. 2006. The timing and duration of the Delamerian orogeny: correlation with the Ross orogen and implications for Gondwana assembly. I. Geol. 114:189-210. doi:10.1086/499570.

Foster, D. A., and Gray, D. R. 2000. Evolution and structure of the Lachlan fold belt (orogen) of eastern Australia.
Annu. Rev. Earth Planet. Sci. 28:47-80. doi:10.1146 /annurev.earth.28.1.47.

Foster, D. A.; Gray, D. R.; and Spaggiari, C. 2005. Timing of subduction and exhumation along the Cambrian East Gondwana margin, and the formation of Paleozoic backarc basins. Geol. Soc. Am. Bull. 117:105-116. doi: 10.1130/B25481.1.

Gehrels, G. E.; Valencia, V. A.; and Ruiz, J. 2008. Enhanced precision, accuracy, efficiency, and spatial resolution of $\mathrm{U}-\mathrm{Pb}$ ages by laser ablation-multicollector-inductively coupled plasma-mass spectrometry. Geochem. Geophys. Geosvs. 9:Q03017. doi:10.1029/2007GC001805.

Goodge, J. W. 1997. Latest Neoproterozoic basin inversion of the Beardmore Group, central Transantarctic Mountains, Antarctica. Tectonics 16:682-701. doi:10.1029 $197 \mathrm{TC} 01417$.

2007. Metamorphism in the Ross orogen and its bearing on Gondwana margin tectonics. GSA Spec. Pap. 419:185-203. doi:10.1130/2006.2419(10).

Goodge, J. W.; Borg, S. G.; Smith, B. K.; and Bennett, V. C. 1991. Tectonic significance of Proterozoic ductile shortening and translation along the Antarctic margin of Gondwana. Earth Planet. Sci. Lett. 102:58-70. doi: 10.1016/0012-821X(91)90017-C.

Goodge, J. W., and Dallmeyer, R. D. 1992. ${ }^{40} \mathrm{Ar} /{ }^{39} \mathrm{Ar}$ mineral age constraints on the Paleozoic tectonothermal evolution of high-grade basement rocks within the Ross orogen, central Transantarctic Mountains. I. Geol. 100:91-106. doi:10.1086/629573.

1996. Contrasting thermal evolution within the Ross orogen, Antarctica: evidence from mineral ages. I. Geol. 104:435-458.

Goodge, J. W.; Fanning, C. M.; and Bennett, V. C. 2001. U$\mathrm{Pb}$ evidence of $\sim 1.7 \mathrm{Ga}$ crustal tectonism during the Nimrod Orogeny in the Transantarctic Mountains, Antarctica: implications for Proterozoic plate reconstructions. Precambrian Res. 112:261-288. doi:10.1016/S0301 -9268(01)00193-0.

Goodge, J. W.; Fanning, C. M.; Norman, M. D.; and Bennett, V. C. 2012. Temporal, isotopic and spatial relations of early Paleozoic Gondwana-Margin arc magmatism, central Transantarctic Mountains, Antarctica. I. Petrol. 53:2027-2065. doi:10.1093/petrology /egs043.

Goodge, J. W., and Finn, C. A. 2010. Glimpses of East Antarctica: aeromagnetic and satellite magnetic view from the central Transantarctic Mountains of East Antarctica. I. Geophys. Res. 115:1-22. doi:10.1029 /2009JB006890.

Goodge, J. W.; Myrow, P.; Phillips, D.; Fanning, C. M.; and Williams, I. S. 2004a. Siliciclastic record of rapid denudation in response to convergent-margin orogenesis, Ross Orogen, Antarctica. Spec. Pap. Geol. Soc. Am. 378:105-126. doi:10.1130/0-8137-2378-7.105.

Goodge, J. W.; Myrow, P.; Williams, I. S.; and Bowring, S. A. 2002. Age and provenance of the Beardmore Group, Antarctica: constraints on Rodinia supercontinent breakup. I. Geol. 110:393-406. doi:10.1086/340629. 
Goodge, J. W.; Walker, N. W.; and Hansen, V. L. 1993. Neoproterozoic-Cambrian basement-involved orogenesis within the Antarctic margin of Gondwana. Geology 21:37-40. doi:10.1130/0091-7613(1993) 021<0037:NCBIOW>2.3.CO;2.

Goodge, J. W.; Williams, I. S.; and Myrow, P. 2004b. Provenance of Neoproterozoic and lower Paleozoic siliciclastic rocks of the central Ross orogen, Antarctica: detrital record of rift-, passive-, and active-margin sedimentation. Geol. Soc. Am. Bull. 116:1253-1279.

Grunow, A. M., and Encarnación, J. P. 2000a. CambroOrdovician palaeomagnetic and geochronologic data from southern Victoria Land, Antarctica: revision of the Gondwana apparent polar wander path. Geophys. I. Int. 141:392-400.

2000b. Terranes or Cambrian polar wander: new data from the Scott Glacier area, Transantarctic Montains, Antarctica. Tectonics 19:168-181.

Grunow, A.; Encarnación, J. P.; Paulsen, T. S.; and Rowell, A. J. 1996a. New geologic constraints on basement rocks from the Shackleton Glacier region. Antarct. J. U.S. 31:18-19.

Grunow, A.; Hanson, R.; and Wilson, T. 1996b. Were aspects of Pan-African deformation linked to Iapetus opening? Geology 24:1063-1066.

Gunn, B. M., and Warren, G. 1962. Geology of Victoria Land between the Mawson and Mulock Glaciers, Antarctica. N. Z. Geol. Surv. Bull. 71, 157 p.

Hagen-Peter, G., and Cottle, J. M. 2016. Synchronous alkaline and subalkaline magmatism during the late Neoproterozoic-early Paleozoic Ross orogeny, Antarctica: insights into magmatic sources and processes within a continental arc. Lithos 262:677-698. doi: 10.1016/j.lithos.2016.07.032.

Hagen-Peter, G.; Cottle, J. M.; Smit, M.; and Cooper, A. F. 2016. Coupled garnet Lu-Hf and monazite U-Pb geochronology constrain early convergent margin dynamics in the Ross orogen, Antarctica. I. Metamorph. Geol. 34:293-319. doi:10.1111/jmg.12182.

Hagen-Peter, G.; Cottle, J. M.; Tulloch, A. J.; and Cox, S. C. 2015. Mixing between enriched lithospheric mantle and crustal components in a short-lived subduction-related magma system, Dry Valleys area, Antarctica: insights from U-Pb geochronology, Hf isotopes, and whole-rock geochemistry. Lithosphere 7: 174-188. doi:10.1130/L384.1.

Hall, C. E.; Cooper, A. F.; and Parkinson, D. L. 1995. Early Cambrian carbonatite in Antarctica. I. Geol. Soc. Lond. 152:721-728. doi:10.1144/gsigs.152.4.0721.

Hoskin, P. W. O., and Schaltegger, U. 2003. The composition of zircon and igneous and metamorphic petrogenesis. Rev. Mineral. Geochem. 53:27-62. doi:10 $.2113 / 0530027$.

Jacobs, J. 1999. Neoproterozoic/Lower Palaeozoic events in central Dronning Maud Land (East Antarctica). Gondwana Res. 2:473-480.

Laird, M. G.; Mansergh, G. D.; and Chappell, J. M. A. 1971. Geology of the central Nimrod Glacier area,
Antarctica. N. Z. I. Geol. Geophys. 14:427-468. doi: 10.1080/00288306.1971.10421939.

Ludwig, K. 2008. Isoplot 3.6. Berkeley Geochronol. Cent. Spec. Publ. 4, 77.

Martin, A. P.; Cooper, A. F.; Price, R. C.; Turnbull, R. E.; and Roberts, N. M. W. 2015. The petrology, geochronology and significance of Granite Harbour Intrusive Complex xenoliths and outcrop sampled in western McMurdo Sound, southern Victoria Land, Antarctica. N. Z. I. Geol. Geophys. 58:33-51. doi:10.1080/00288306 .2014.982660.

McGregor, V. R. 1965. Notes on the geology of the area between the heads of the Beardmore and Shackleton glaciers, Antarctica. N. Z. I. Geol. Geophys. 8:278291. doi:10.1080/00288306.1965.10428111.

Mellish, S. D.; Cooper, A. F.; and Walker, N. W. 2002. Panorama Pluton: a composite gabbro-monzodiorite early Ross Orogeny intrusion in southern Victoria Land, Antarctica. In Gamble, J. A.; Skinner, D. N. B.; and Henrys, S., eds. Antarctica at the close of a millennium. R. Soc. N. Z. Bull. 35:125-141.

Millar, I. L., and Storey, B. C. 1995. Early Palaeozoic rather than Neoproterozoic volcanism and rifting within the Transantarctic Mountains. I. Geol. Soc. Lond. 152:417-420. doi:10.1144/gsigs.152.3.0417.

Mirsky, A. 1969. Geology of the Ohio Range-Liv Glacier area. Am. Geogr. Soc., Antarctic Map Folio Series, fol. 12 , pl. 16 .

Murtaugh, J. G. 1969. Geology of the Wisconsin Range batholith, Transantarctic Mountains. N. Z. I. Geol. Geophys. 12:526-550. doi:10.1080/00288306.1969 .10420297.

Myrow, P. M.; Pope, M. C.; Goodge, J. W.; Fischer, W.; and Palmer, A. R. 2002. Depositional history of pre-Devonian strata and timing of Ross orogenic tectonism in the central Trananarctic Mountains, Antarctica. Bull. Geol. Soc. Am. 114:1070-1088. doi:10.1130/0016-7606(2002) 114<1070:DHOPDS >2.0.CO;2.

Paulsen, T. S.; Deering, C.; Sliwinski, J.; Bachmann, O.; and Guillong, M. 2016a. A continental arc tempo discovered in the Pacific-Gondwana margin mudpile? Geology 44:915-918. doi:10.1130/G38189.1.

2016b. Detrital zircon ages from the Ross Supergroup, north Victoria Land, Antarctica: implications for the tectonostratigraphic evolution of the Pacific-Gondwana margin. Gondwana Res. 35:79-96. doi:10.1016/j.gr.2016.04.001.

- 2017. Evidence for a spike in mantle carbon outgassing during the Ediacaran period. Nat. Geosci. doi:10.1038/s41561-017-0011-6.

Paulsen, T. S.; Encarnación, J.; and Grunow, A. M. 2004. Structure and timing of transpressional deformation in the Shackleton Glacier area, Ross orogen, Antarctica. I. Geol. Soc. Lond. 161:1027-1038. doi:10.1144/0016 -764903-040.

Paulsen, T. S.; Encarnación, J.; Grunow, A. M.; Layer, P. W.; and Watkeys, M. 2007. New age constraints for a short pulse in Ross orogen deformation triggered 
by East-West Gondwana suturing. Gondwana Res. 12: 417-427. doi:10.1016/j.gr.2007.05.011.

Paulsen, T. S.; Encarnación, J.; Grunow, A. M.; and Pecha, M. 2016c. Zircon U-Pb age constraints for a Cambrian age for metasedimentary rocks at O'Brien Peak, Antarctica. N. Z. I. Geol. Geophys. 59:592-597. doi: 10.1080/00288306.2016.1182033.

Paulsen, T. S.; Encarnación, J.; Grunow, A. M.; Valencia, V. A.; Layer, P. W.; Pecha, M.; Stump, E.; Roeske, S.; Thao, S.; and Rasoazanamparany, C. 2015. Detrital mineral ages from the Ross Supergroup, Antarctica: implications for the Queen Maud terrane and outboard sediment provenance on the Gondwana margin. Gondwana Res. 27:377391. doi:10.1016/j.gr.2013.10.006.

Paulsen, T. S.; Encarnación, J.; Grunow, A. M.; Valencia, V. A.; Pecha, M.; Layer, P. W.; and Rasoazanamparany, C. 2013. Age and significance of "outboard" highgrade metamorphics and intrusives of the Ross orogen, Antarctica. Gondwana Res. 24:349-358. doi:10.1016 /j.gr.2012.10.004.

Paulsen, T. S.; Encarnación, J.; Grunow, A. M.; Valencia, V. A.; and Rasoazanamparany, C. 2008. Late sinistral shearing along Gondwana's Paleo-Pacific margin in the Ross Orogen, Antarctica: new structure and age data from the O'Brien Peak area. I. Geol. 116:303-312. doi:10.1086/587727.

Read, S. E. 2010. Koettlitz Glacier alkaline province: Late Neoproterozoic extensional magmatism in southern Victoria Land, Antarctica. PhD thesis, University of Otago.

Read, S. E.; Cooper, A. F.; and Walker, N. W. 2002. Geochemistry and U-Pb geochronology of the Neoproterozoic-Cambrian Koettlitz Glacier alkaline province, Royal Society Range, Transantarctic Mountains, Antarctica. In Gamble, J. A.; Skinner, D. N. B.; and Henrys, S., eds. Antarctica at the close of a millennium. R. Soc. N. Z. Bull. 35:143-151.

Rocchi, S.; Bracciali, L.; Di Vincenzo, G.; Gemelli, M.; and Ghezzo, C. 2011. Arc accretion to the early Paleozoic Antarctic margin of Gondwana in Victoria Land. Gondwana Res. 19:594-607. doi:10.1016/j.gr.2010.08.001.

Rowell, A. J.; Gonzales, D. A.; McKenna, L. W.; Evans, K. R.; Stump, E.; and Van Schmus, W. R. 1997. Lower Paleozoic rocks in the Queen Maud Mountains: revised ages and significance. In The Antarctic region: geological evolution and processes. Siena, Terra Antarctica, p. 201-207.

Rowell, A. J., and Rees, M. N. 1989. Early Palaeozoic history of the upper Beardmore Glacier area: implications for a major Antarctic structural boundary within the Transantarctic Mountains. Antarct. Sci. 1:249260. doi:10.1017/S0954102089000374.

Rowell, A. J.; Rees, M. N.; and Duebendorfer, E. 1993. An active Neoproterozoic margin: evidence from the Skelton Glacier area, Transantarctic Mountains. I. Geol. Soc. Lond. 150:677-682. doi:10.1144/gsigs.150.4.0677.

Rowell, A. J.; Rees, M. N.; and Evans, K. R. 1992. Evidence of major Middle Cambrian deformation in the Ross
Orogen, Antarctica. Geology 20:31-34. doi:10.1130 /0091-7613(1992)020<0031:EOMMCD>2.3.CO;2.

Rubatto, D. 2002. Zircon trace element geochemistry: partitioning with garnet and the link between $\mathrm{U}-\mathrm{Pb}$ ages and metamorphism. Chem. Geol. 184:123-138. doi:10.1016/S0009-2541(01)00355-2.

Squire, R. J.; Campbell, I. H.; Allen, C. M.; and Wilson, C. J. L. 2006. Did the Transgondwanan Supermountain trigger the explosive radiation of animals on Earth? Earth Planet. Sci. Lett. 250:116-133. doi:10.1016/j .epsl.2006.07.032.

Squire, R. J., and Wilson, C. J. L. 2005. Interaction between collisional orogenesis and convergent-margin processes: evolution of the Cambrian proto-Pacific margin of East Gondwana. I. Geol. Soc. 162:749-761. doi:10.1144/0016-764904-087.

Stacey, J. S., and Kramers, J. D. 1975. Approximation of terrestrial lead isotope evolution by a two-stage model. Earth Planet. Sci. Lett. 26:207-221. doi:10.1016/0012 -821X(75)90088-6.

Stump, E. 1981. Structural relationships in the Duncan Mountains, central Transantarctic Mountains, Antarctica. N. Z. I. Geol. Geophys. 24:87-93. doi:10.1080 /00288306.1981.10422699.

- 1982. The Ross Supergroup in the Queen Maud Mountains. In Craddock, C., ed. Antarctic geoscience. Madison, University of Wisconsin Press, p. 565-569.

. 1985. Stratigraphy of the Ross Supergroup, central Transantarctic Mountains. In Geology of the central Transantarctic Mountains. Washington, DC, American Geophysical Union, p. 225-274. doi:10.1029/AR036 p0225.

1992. The Ross orogen of the Transantarctic Mountains in light of the Laurentia-Gondwana split. GSA Today 2:25-31.

1995. The Ross orogen of the Transantarctic Mountains. Cambridge, Cambridge University Press.

Stump, E.; Gehrels, G.; Talarico, F.; and Carosi, R. 2007. Constraints from detrital zircon geochronology on the early deformation of the Ross orogen, Transantarctic Mountains, Antarctica. In Cooper, A. K.; Raymond, C. R.; et al., eds. Antarctica: a keystone in a changing world. Online Proceedings of the 10th ISAES. USGS Open-File Report 2007-1047, Short Research Paper 072. doi:10.3133/of2007-1047.srp072.

Stump, E.; Gootee, B.; and Talarico, F. 2006. Tectonic model for development of the Byrd Glacier discontinuity and surrounding regions of the Transantarctic Mountains during the Neoproterozoic-early Paleozoic. In Futterer, D.; Damaske, D.; Kleinschmidt, G.; Miller, H.; and Tessensohn, F., eds. Antarctica: contributions to global earth sciences. Berlin, Springer, p. 181-190.

Stump, E.; Gootee, B. F.; Talarico, F.; Van Schmus, W. R.; Brand, P. K.; Foland, K. A.; and Fanning, C. M. 2004. Correlation of Byrd and Selborne groups, with implications for the Byrd Glacier discontinuity, central Transantarctic Mountains, Antarctica. N. Z. I. Geol. Geophys. 47:157-171. doi:10.1080/00288306.2004.9515045. 
Talarico, F. M.; Stump, E.; Gootee, B. F.; Foland, K. A.; Palmeri, R.; Van Schmus, W. R.; Brand, P. K.; and Ricci, C. A. 2007. First evidence of a "Barrovian"-type metamorphic regime in the Ross orogen of the Byrd Glacier area, central Transantarctic Mountains. Antarct. Sci. 19:451-470. doi:10.1017/S0954102007000594.

Turner, S. P.; Kelley, S. P.; Vandenberg, A. H. M.; Foden, J. D.; Sandiford, M.; and Flöttmann, T. 1996. Source of the Lachlan fold belt flysch linked to convective removal of the lithospheric mantle and rapid exhumation of the Delamerian-Ross fold belt. Geology 24:941-944. doi: 10.1130/0091-7613(1996)024<0941:SOTLFB>2.3.CO;2.

Van Schmus, W. R.; McKenna, L. W.; Gonzales, D. A.; Fetter, A. H.; and Rowell, A. J. 1997. U-Pb geochronology of parts of the Pensacola, Thiel, and Queen Maud mountains, Antarctica. In The Antarctic region: geological evolution and processes. Siena, Terra Antarctica, p. 187-200.

Vogel, M. B.; Ireland, T. R.; and Weaver, S. D. 2002. The multistage history of the Queen Maud batholith, La Gorce Mountains, central Transantarctic Mountains. In
Antarctica at the close of a millennium. Proceedings of the 8th International Symposium on Antarctic Earth Sciences, Wellington 1999, p. 153-159.

Wade, F. A., and Cathey, C. A. 1986. Geology of the basement complex, Western Queen Maud Mountains, Antarctica. Antarct. Res. Ser. 36:429-453.

Wareham, C. D.; Stump, E.; Storey, B. C.; Millar, I. L.; and Riley, T. R. 2001. Petrogenesis of the Cambrian Liv Group, a bimodal volcanic rock suite from the Ross orogen, Transantarctic Mountains. Bull. Geol. Soc. Am. 113:360-372. doi:10.1130/0016-7606(2001)113<0360:PO TCLG $>2.0 . C O ; 2$.

Wysoczanski, R. J., and Allibone, A. H. 2004. Age, correlation, and provenance of the Neoproterozoic Skelton Group, Antarctica: Grenville age detritus on the margin of East Antarctica. I. Geol. 112:401416. doi:10.1086/421071.

Wysoczanski, R. J.; Forsyth, P. J.; and Woolfe, K. J. 2003. Zircon dating and provenance of rhyolitic clasts in Beacon conglomerate, southern Victoria Land, Antarctica. Terra Antart. 10:67-80. 